\title{
Information Behavior within the Humanities: Searching or Browsing, Recall or Precision? Researching the Information Needs of Academics: the Case Study of the Faculty of History of the University of Warsaw
}

\author{
Anna Mierzecka \\ Institute of Information Science and Book Studies \\ University of Warsaw, Poland
}

\begin{abstract}
Purpose/thesis: The aim of this research was to discover the characteristics of information behavior among the scholars whose academic focus lies within the field of humanities. Recognizing the importance of local conditions and their impact on information behavior, the researcher conducted her empirical study on a group of Polish academics, i.e. the employees of the Faculty of History at the University of Warsaw. Particular emphasis was put on establishing (1) how academics retrieve required literature, (2) what factors may influence the degree of satisfaction from the query, (3) how crucial was the level of results' relevance and (4) whether academics assign greater importance to query recall or precision.

Approach/methods: Empirical research was preceded by the analysis of subject literature enabling the author of the paper to outline several internationally observed tendencies in information behavior of academics, and to formulate theses with regard to Polish academics. These were verified on the basis of 54 in-depth interviews with the employees of the Faculty of History at the University of Warsaw and their ordered queries of academic literature.

Results and conclusions: Research results have indicated that humanities scholars prefer browsing document sets characterized by a high level of recall as a method of retrieving required subject literature. Due to the difficulty in formulating query instructions with sufficient precision, they less frequently choose the method of searching for document sets characterized by high precision factor. The need to browse through irrelevant titles was found to have no significant impact on the level of user satisfaction. Additional research has also indicated that academic texts databases are still insufficiently adjusted to the needs of humanities scholars.

Originality/value: The research has allowed to describe information behavior of humanities scholars with regard to the use of digital technologies in the research process, which so far has not taken place in the case of Polish academic community.
\end{abstract}

\section{Keywords}

Humanists. Information Behavior. Information Needs. Information Precision. Information Query. Information Recall. Information Seeking. Relevance. Satisfaction of Information Users.

Received:06.05.2015. Revised:08.07.2015. Accepted:09.07.2015. 


\section{Introduction}

The organization of academic communication has recently undergone major transformations. Many point to its increasingly global and networked character, resulting, among others, from the advancing digitalization, development of Science 2.0 initiatives, emergence of new tools for knowledge organization (Sosińska-Kalata, 2011) as well as the creation of informational infrastructure for science. Its integral part consists of special information retrieval systems whose aim should be to facilitate efficient access to academic literature and information sources in a manner corresponding to the specific character of the discipline represented by the researcher. Effective information flow, understood as retrieving relevant messages, that is, among others, pertinent academic publications, should also be supported by an appropriate system of services provided by informational specialists to the academic community. Preparation of such infrastructure must be based on the research of information needs.

Among the factors that significantly determine information needs of scholars is the academic field their research is located in. In the case of humanities, research process is largely based on working with texts: reading, analysis, synthesis and interpretation of materials that are usually made available through libraries and archives. Research results have confirmed that humanities scholars use libraries to a significantly larger degree than the representatives of other disciplines (Whitmire, 2002).

\section{Literature review}

Characteristics of information needs of this particular group have been the subject of numerous studies. Many of these focus on the relation between the specifics of academic communication and the rapidly developing information-communication technologies (ICT) transforming, in turn, also the academics' information needs. Research has been conducted within different environments as a significant number of factors impacting information behavior relates to local conditions. Still, while reviewing research results concerning information behavior of the humanists from different countries, one notices certain common tendencies.

Among the conclusions resurfacing throughout the research conducted in the period when ICT tools were only beginning to be implemented into the research process is the observation that humanities scholars are negative about the use of technology in that regard. Such is the conclusion of Stone's (1982) research but also of later studies from the period when the commonly available ICT potential brought about major changes in the process of academic communication (Buchanan, Cunningham, Blandford, Rimmer, \& Warwick, 2005; Graham, 2000). It was found that humanities scholars are slower to learn and embrace new technologies than the representatives of other academic fields (Tahir, Mahmood, \& Shafique, 2010), while older scholars believe that they do not need to use those at all (Al-Shboul \& Abrizah, 2014; Wiberley \& Jones, 2000). Preference for the use of printed materials rather than digital ones was revealed by the survey conducted among 250 scholars from the field of arts and humanities (Palmer \& Neumann, 2002), as well as by the Dalton and Charnigo research (2004) conducted among historians, and further, by 
the comparison of the degree to which those two types of materials were used in the work of Israeli humanists (Bronstein \& Baruchson-Arbib, 2008). Research conducted by Tibbo (2003) among historians (700 scholars from 68 American universities) has also shown that they retrieve required texts by tracing citations in printed materials, as was claimed by $98 \%$ of respondents. Analyzing the use of digital journals and databases of academic texts by the representatives of various disciplines, Talja and Maula (2003) described humanists as "low level users" of such sources.

The majority of previously referenced studies is more than a decade old, and the possibilities of ICT, including the tools designed to simplify the research process, have changed dramatically in that period. Even such basic tools as library catalogues and reference managers have become more intuitive and more user-friendly. Also the humanists' attitude toward the use of technology has transformed: this has been observed already by some of the earlier research, conducted 10 years ago: Bass, Fairlee, Fox, and Sullivan (2005) found a growth in the use of digital information sources among the humanists accompanied by a decline in the use of printed materials. Similarly, Rimmer, Warwick, Blandford, Gow, and Buchanan (2006) noticed an increased use of digital technologies both in the process of searching for materials and in the use of digital documents. More recent studies leave no doubt that although humanists face several difficulties in using digital technologies for the research process, they view them as useful and helpful in facilitating academic work (i.e. Al-Shboul \& Abrizah, 2014; Madden, 2014; Tahir et al., 2010; Toms \& O’Brien, 2008).

However, those rapid changes have not affected humanists' information needs related to the specific character of their research, also with regard to digital technologies. Presented research has allowed to identify specific information behavior typical of humanities scholars. Among such behaviors is their method of retrieving required documents, both primary and secondary: humanities scholars tend to look for texts by browsing specific collections of documents rather than by using precisely formulated search instructions. Such observations were confirmed by numerous studies, both those conducted before the popularization of the Internet (Bouazza, 1989; Gould, 1988; Watson-Boone, 1994) and the more recent ones, where browsing through document collections takes place online (Al-Shboul \& Abrizah, 2014; Brockman, Neumann, Palmer, \& Tidline, 2001; Dalton \& Charnigo, 2004; Tahir et al., 2010; Talja \& Maula, 2003; Toms \& O’Brien, 2008). There are several reasons why the browsing through document collections is the preferred method of searching for sources among humanities scholars. Firstly, defining query instructions clearly and unambiguously is difficult within their field of research. The difficulty is linked, among others, to the lack of commonly accepted terminology: different sub-disciplines may describe the same phenomena using different terms. This translates directly to the difficulty of formulating an adequately precise query for textual databases. It is an obstacle encountered both by scholars using databases indexing texts in their native language (Tahir et al., 2010), and by those who additionally face the problem of having to reflect the topic of their research in a language different from their own (Bates, 1996).

Another issue warranting attention in describing the specifics of information retrieval by the scholars representing the humanities is the fact that the entire nature of the research process in this case is usually non-linear, not systematized, and sometimes even random (Tahir et al., 2010; Talja \& Maula, 2003). Describing the mode of work within humanities, Blitzer (1967) states: 
the journey is as important as the destination, and an account of the journey is as important as a picture of the destination (228).

This impacts also the method of searching for literature as an integral part of the process. As observed by Palmer and Neumann (2002), humanists value browsing the entire collection on a topic over retrieving a particular document. This is frequently related to the fact that they are also interested in documents only loosely tied to the main topic of research, ones that may put it in different light. These observations were confirmed in the research conducted by Al-Shboul and Abrizah (2014), while Dalton and Charnigo (2004) point out that for humanities, the "depth" of the query is far more important than the relevance of found materials. Another factor explaining the prevalence of browsing as a method of obtaining literature is the fact that within humanities, there are no temporary restrictions on the value of research materials - the majority of humanists refrain from citing only the newest publications (Toms \& O’Brien, 2008).

One could expand on the characteristics of the research work performed within humanities addressing several other important issues, such as the undiminished importance of book publications, problems related to the locality of topics and the resulting specificity of citations, however, for the purpose of this article the author has decided to limit the scope of investigation to the questions of information behavior, in particular to the issue of information query.

\section{Purpose of the study}

Recognizing the importance of the impact of local conditions on information behavior, the author has decided to test in Polish conditions the observations presented and discussed in the literature review section of the present article. The study was conducted among the employees and doctoral candidates of the Faculty of History, University of Warsaw. ${ }^{1}$ Conducted research was qualitative in nature and so called humanistic research perspective was adapted, which did not entail abandoning problem pre-conceptualization. However, hypotheses were formulated as very general assumptions outlining directions for the description of studied reality. Efforts were made, among others, to determine whether algorithmic relevance and subject relevance were a dominant influence on the level of satisfaction for humanities scholars, or whether other, equally important or more important, factors could be identified. This seemed justified in the time of prevalent information overload, when finding documents fulfilling the criteria of algorithmic relevance is easier than the process of selecting actually pertinent publications. The same premise served as a basis for the thesis about the importance of query results optimization, which would translate into a greater importance of the precision factor, compared to the importance of recall, for the satisfaction of end users.

${ }^{1}$ This research constitutes the empirical part of the research process described in Badania zachowań informacyjnych (Mierzecka-Szczepańska, 2013). Research results presented in this article are a part of the gathered material that has not been published so far. 


\section{Methodology}

In-depth interviews with project participants were chosen as the most suitable method to verify the outlined hypotheses. 27 out of 273 employees of the Faculty of History took part in the study: among them 18 academic employees and 9 doctoral candidates. This way of sampling allowed to differentiate results depending on the researchers' experience: PhD students are the group which begins academic work while holders of a doctoral degree have already a substantial degree of research experience ${ }^{2}$. Two interviews were conducted with each participant (a total of 54 interviews). In order to learn about the information behavior of the chosen group, conditions were created for the respondents to describe what kind of materials they needed for academic work, after which they ordered a query for the required materials in the databases of academic texts. Resulting sets of materials were later evaluated by the respondents. The interviews conducted with each respondent included one taking place before the realization of the query and one taking place after the query results were submitted. Both interviews, as well as with queries for relevant materials and their pre-selection, were conducted by the author of the present study. ${ }^{3}$

\section{Findings and discussion}

Before the presentation of research results, it is crucial to refer to the specifics of literature queries within humanities. The adopted research process has allowed to verify the difficulties described in subject literature, associated with the use of electronic databases with respect to the ordered query topics.

One should begin with the difficulty of obtaining a set of results characterized by a high level of subject relevance. Algorithmic relevance (the congruence of terms used in the query instruction with the terms used in Information Retrieval System) is today ensured by the high quality of contemporary IR Systems and, except for the rare instances of database malfunctions, does not pose a significant problem. However, the issue of subject (i.e. congruence of terms used in the query instruction with the query subject - or the research topic) proved more complex. As discussed earlier, in the overview of subject literature, humanities pose a challenge greater than sciences with regard to defining precisely the topic of the query. Even respondents themselves believed the topics of their queries to be difficult, or almost impossible, to define precisely (as claimed by 19 out of 27 respondents). Moreover, even those topics that were seemingly easy to formulate proved difficult to translate into an instruction appropriate for the given system, and the query process

${ }^{2}$ A full discussion of the empirical part of the study related to the experience of respondents is described in Badania zachowań informacyjnych (Mierzecka-Szczepańska, 2013).

3 The method of realizing the query (i.e. selection of databases, preparing the query instruction) was continuously consulted with the respondents. All in all, 5636 documents were retrieved in 27 queries. In order not to affect the research results, materials retrieved using the strategy approved by the respondents were not excluded from the set of results even when they were irrelevant. The results list, however, was divided in two parts: recommended positions and other, aiming to facilitate easier navigation through query results. After standardizing bibliographical descriptions and completing the missing metadata, results lists were communicated to the respondents as results of query completion and a basis for the evaluations discussed in the closing interview. 
itself - highly complicated. Let us take a closer look at one example. The query was to focus on "travelling across Europe during the early-modern times (between the 16th and the 18th centuries)". For this kind of query JSTOR is one of the databases one could expect interesting results from, and so the instruction was formulated as follows:

\begin{abstract}
("Grand tour" or "Grand tours" or "peregrinatio academica" or Kavalierstour or Cavalierstour or Cavaliertour or Kavalierreise or Bildungsreise or Junkerfahrt or "Tour du Chevalier" or "educational journey" or "educational trip") and ("16 century" or "XVI century" or "sixteenth century" or "17 century" or "XVII century" or "seventeenth century" or "18 century" or "XVIII century" or "eighteenth century" or "16 Jahrhundert "or "XVI Jahrhundert" or "sechzehnte Jahrhundert" or "17 Jahrhundert" or "XVII Jahrhundert" or "siebzehnte Jahrhundert" or "18 Jahrhundert" or "XVIII Jahrhundert" or "achtzehnte Jahrhundert" or "16 secolo" or "XVI secolo" or "sedicesimo secolo" or "17 secolo" or "XVII secolo" or "diciassettesimo secolo" or "18 secolo" or "XVIII secolo" or "diciottesimo secolo" or "16 siecle" or "XVI siecle" or "seizième siecle" or "17 century" or "XVII siecle" or "dix-septième siecle" or "18 siecle" or "XVIII siecle" or "dix-huitième siecle") and (Europe or Germany or Italy or France or England or Netherlands or Britain or Europa or Deutschland or Italien or Frankreich or Niederlande or Großbritannien or Britannien or Germania or Italia or Francia or Inghilterra or "Paesi Bassi “ or Bretagna or Allemagne or Italie or France or Angleterre or Pays-Bas or Grande-Bretagne).
\end{abstract}

As JSTOR is searched mainly for titles and full texts, the instruction ought to include terms in the languages of interest to the searching party. Instruction in the form presented above proved too long to be entered into the search engine and had to be divided into parts. As for the instruction reflecting the period that the retrieved materials were supposed to concern, and the geographical areas, one could still wonder whether the instruction is sufficiently comprehensive. At the same time, it serves as a good illustration of the problems related to the nature of research topics in humanities. Instructions turned to be even more complicated for queries of even less precisely defined scope.

Reflecting upon the issues of subject relevance one must also note the problems unrelated to the query formulation, namely the deteriorating quality of metadata introduced into IR Systems. It is not even a matter of common errors in content description but of erroneous selection of keywords for indexing. Two examples below present extreme cases of how negligent attribution of subject terms renders useless the search process. The first description comes from Scopus (accessed on 29 March 2015):

Fang, X., L. Zhao, et al. (2006). "Studying on the life cycle information share and discovery for complicated products based on data mining and data grid technology". Materials Science Forum 532-533: 1120-1123.

Index keywords:

(e, 3e) process; (I,J) conditions; (OTDR) technology; Complicated products; Cooperative design (co design); Data grids; Dynamic alliance; Grey clustering; information discovery; information sharing; Integrated Information Systems; International (CO); Life cycle information; Materials manufacturing; Multilayer (ML); Operation and maintenance (OAM); product life cycles; Administrative data processing; Algorithms; Architectural design; Boolean functions; Cluster analysis; Clustering algorithms; Computer networks; Data mining; Decision support systems; Digital libraries; Dynamical systems; Dynamics; Evolutionary algorithms; Flow of solids; Grid computing; Information management; Information systems; Knowledge management; Large scale systems; Life cycle; Management information systems; Marketing; Mechanics; Mining; Network protocols; Pigments; Process design; Process engineering; Product design; Product development; Scheduling algorithms; Search engines; Service life; Ships; Technology 
In the example above keywords selected to describe the content of the paper are not only numerous but also irrelevant (for instance "mining" or "pigments"). Presumably, the selection of keywords was performed automatically. This, however, leads to a situation where similar results may be obtained by searching full texts of articles, and far more precise ones when the search is restricted to abstracts or publication titles. Interestingly, this number of keywords was used for an article which, as the bibliographical description indicates, is only three pages long. Looking at the set of keywords above, one may wonder what the purpose of metadata prepared in such form could possibly be.

The second example reveals lacks in terminology reflecting some aspects of the article's content, frequent also in non-automatic search information systems. The description of the publication was taken from Library, Information Science and Technology Abstracts (LISTA; accessed on 29 March 2015):

\footnotetext{
Garlick, M. (1996). "Cinderella comes to the ball: Government information through public libraries”. APLIS 9 (3/4): 156.

Abstract: Demonstrates the potential for public libraries to provide electronic access to government information for the general population. Discussion of a proposed federal government program in Australia; Examples of such initiatives in the country; Issues significant to the development of access to government information.

Subject Terms:

LIBRARY information networks; GOVERNMENT information
}

The second example comes from a database from the field of library and information science. The list of keywords fails to include term as important as "public libraries", particularly vital for the content description. Although "public libraries" is a term listed in the database index, for reasons unknown it was not used as a subject term for the discussed paper. Several similar instances can be found in LISTA. As a result, also in the case of this database, more reliable results will be obtained by searching via uncontrolled terms rather than terms included in the subject index.

Both examples illustrate the problems typically encountered while searching databases for subjects related to the field of humanities. Clearly, despite the developments in digital technologies, the issues of the inadequacy of tools and metadata to the needs of humanities remain unresolved. (Bates, 1996; Brockman et al., 2001; Tahir et al., 2010; Toms \& O’Brien, 2008).

This is why queries formulation for materials adequate to the needs of humanists pose a particularly challenging task. However, this research also attempted to answer the question whether it is truly expected by humanists ordering queries to obtain results highly relevant to queries. As mentioned before, this research posited a hypothesis of the importance of optimizing search results, which would translate into a greater importance of the precision factor rather than recall for the satisfaction of end users. This hypothesis was based on rational choice theory.

The idea of rationality and especially models relying on the analysis of rational behavior have been applied in economy for the analysis of market behaviors. The beginnings of rational choice theory involved the use of John von Neumann and Oskar Morgenstern's game and decision theory in economy and political sciences. In sociology, the works of G. S. Becker, the 1992 winner of the Nobel prize for economy, were of particular importance, 
especially The Economic Approach to Human Behavior from 1976 (translated to Polish as "Ekonomiczna teoria zachowań ludzkich") (Becker, 1990) and the 1964 Human Capital (Becker, 1964). The theory is based on the principle of methodological individualism, an assumption that social phenomena can only be explained through the actions of the individuals, and on the belief in the rationality of individuals who are characterized by determined hierarchies of values, preferences and utility and who take actions aimed at optimization of results understood as maximization of gains and minimization of costs. It is worth emphasizing that while choices result from individual preferences or tastes, this does not exclude, for instance, altruistic behaviors. Rational choice theory does not explain the origin of preferences. But what is important for an analysis of preferences is not only their order but also their intensity; it is also noteworthy that individual choices are more than a consequence of adopted hierarchies: they are also a result of acknowledging the limited character of resources and the related costs, as well as limitations such as norms, laws, rules of the game etc. (Jasińska-Kania, 2006; Lissowski, 2002) Nonetheless, in this research references to rational choice theory are not of sociological character - they only serve as a basis for adopting the hypothesis that humanists (as well as other information users) following the rule of maximization of gains and minimization of costs (of all kinds, including also invested effort and time), unless the specific character of the research tasks decides otherwise, do not proclaim the potentially highest recall factor to be an indispensable condition of satisfactory query.

Figure 1. Assessment of the level of importance assigned to query recall and precision as stated by the respondents in the introductory interview

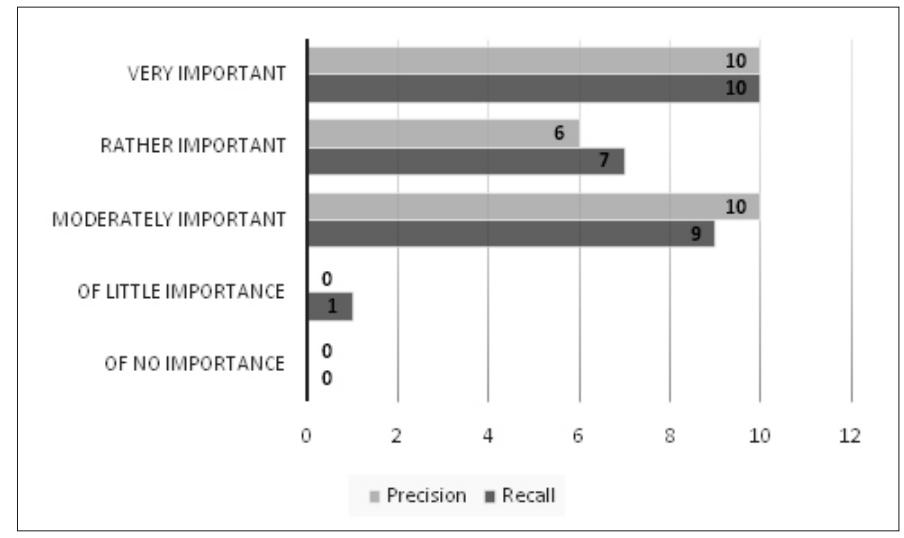

During the introductory interview, respondents were explained the classical relation between Cleverdon's information retrieval effectiveness measurements ${ }^{4}$ : recall and precision.

${ }^{4}$ Those were introduced by James Perry and Alan Kent in 1957 in the so called "Cranfield experiments" conducted under the supervision of Cyril Cleverdon at the Cranfield Institute of Technology. They were among the first tests and studies of information retrieval systems to show that changes in the value of those two measurements are interrelated. If in a conducted query the search instruction is modified to increase the recall factor, one will also observe a gradual decrease of the precision factor and the other way around (see: Mierzecka-Szczepańska, 2012). 
However, as indicated by Figure 1, they were not able to decide which of the parameters was of greater importance for the ordered query.

The following stage of the research allowed to verify this ambiguity, showing which of the measurements proved to be more important to the respondents. During the first interview, as many as 19 out of 27 respondents ordered queries for all publications on their topic of interest, even though they were given various options of limiting the number of supplied publications. During the second interview, they were asked about reasons for such decision.

Figure 2. Reasons behind the decision to order a query for all available relevant documents

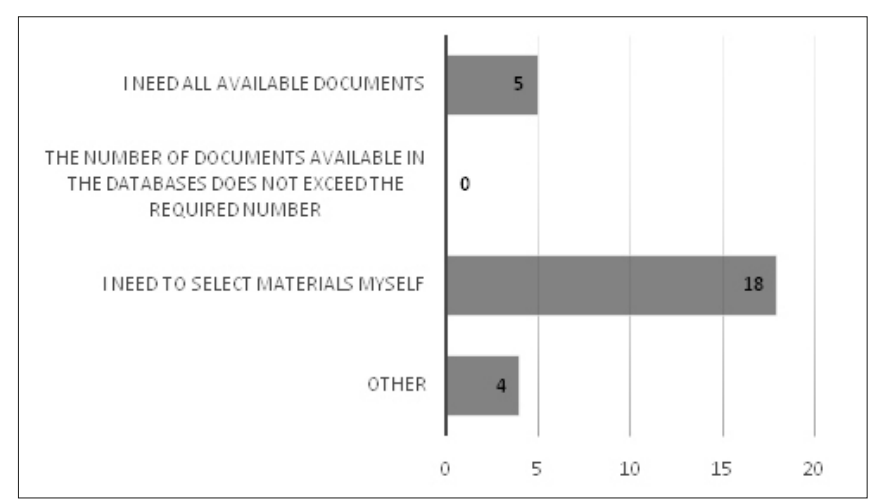

Answers presented in Figure 2 are not disjunctive or mutually exclusive - in an attempt to investigate closely the possible explanation for the situation in question, respondents were allowed to present several reasons for their preference. As one can see, the need to familiarize oneself with the entirety of collected material and to personally select pertinent documents proved to be dominant. Such choice seems to indicate that for the majority of the respondents, search results should be characterized by a high recall factor. This is consistent with the results obtained by Neumann (2002) who found that humanists do not familiarize themselves with single documents but browse entire collections, as well as with the observations by Dalton and Charnigo (2004) that the depth (in this case, recall) of the query is more important than its relevance (precision) and with several other earlier works that indicated browsing as a way of locating literature typical of the humanists.

The validity of this statement was additionally indirectly confirmed by two further questions. First, the respondents were asked about the usefulness of the division of query results into two groups (recommended and other sources) conducted by another person. A significant group (17 persons) appreciated the usefulness of such an ordering of query results, stating that such organization of retrieved documents facilitated and expedited their work. However, in spite of this, 24 out of 27 respondents claimed that they believed it was necessary to familiarize themselves with both sets of query results. They were not only worried that relevant results may have been misclassified but also convinced that the other category may also include interesting papers, not related directly to the main subject of the query. Such behavior echoes the ones observed by Al-Shboul and Abrizah, who state that: 
peripheral documents allows humanities scholars to fulfill their research information needs that has not yet been formulated (Al-Shboul \& Abrizah, 2014, 506).

The second observation concerns the respondents' personal use of academic databases: 9 among them had no previous experience in using such systems but the majority of the remaining group (11 persons) declared that they have been using JSTOR. JSTOR is a database very rich in materials from the field of humanities but also one with rather limited search capabilities - allowing mainly for searching by titles and full texts, which usually produces very extensive results that later need to be reviewed. The results of interviews revealed that respondents do not perceive it as a significant problem but rather as a specificity of conducting research within humanities. This observation also confirms that the studied group prefers to work with a complete set of materials and that they do not find a relatively low precision factor discouraging.

In the final stage of the research the respondents were asked about the influence of the number of irrelevant search results on the level of satisfaction from the query. The respondents based their answers on the experience gathered throughout the project but the question was general in its scope and did not concern only the query conducted in the project.

Figure 3. The influence of irrelevant positions on the level of query satisfaction

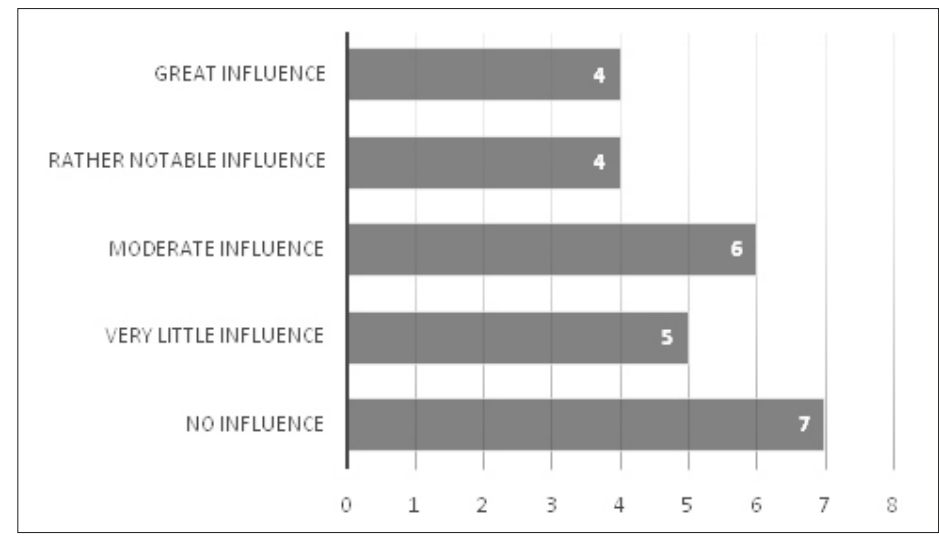

Looking at Figure 3 one will note a relation between the number irrelevant search results and the level of satisfaction of information users, but to a far lesser degree than it had been assumed while adopting initial hypotheses. According to 12 respondents, irrelevant positions had no influence or very little influence on their query satisfaction, which was greatly surprising. It had been assumed that in the case of academic employees, who, in the first interview, declared that they have insufficient time to conduct research, the necessity to review irrelevant results would reveal itself as a strongly discouraging factor. This observation confirms yet again that according to the respondents, precision factor does not have a decisive influence on the sense of query satisfaction.

The results of this research allow for several observations consistent with the results of international studies. The respondents complained about the lack of literature databases 
containing not only subject literature but also primary sources, similarly to what was observed by Tahir et al. (2010) as well as by the authors of earlier studies (Dalton \& Charnigo, 2004; Toms \& Flora, 2005; Wiberley \& Jones, 2000). The respondents stressed the uselessness of literature databases which despite offering full access to texts offer no option to download them, pointing out that the specificity of humanities as a research domain requires the possibility to work with the texts and to annotate them regardless of online access. The importance of creating appropriate opportunities to work with texts as a necessary requirement for the professional research in humanities is among the main conclusions by Toms and O'Brien (2008). They have also noted that scholars in humanities are not willing to pay for the texts available online using their own resources or research funds, presumably as a result of humanists' habit to use library resources that they can usually access free of charge. Similarly, none of the respondents in the conducted research expressed willingness to pay for the online access to texts using own research funds. These are only selected observations made throughout the research, the remaining ones were described more broadly and in depth by Mierzecka-Szczepańska (2013).

\section{Conclusion}

Observations described in this paper must be placed within the context of the specificity of this research. One should also note that the falsification of the hypothesis according to which precision factor is more important than the recall factor for query satisfaction does not negate the validity of using rational choice theory to explain information behavior of the studied group. Its narrow interpretation - that recall factor is of lesser importance proved to be of no use. However, in the context of the entire research situation, particularly when considering the specific character of literature databases still lacking tools adequate for the needs of humanists, striving toward a possibly complete set of documents is a rational behavior. This also explains the confirmation of the hypothesis about the lack of decisive influence of the results' relevance (with regard to the subject of the query) on the users' satisfaction.

Research presented here is qualitative in nature; it was conducted on a small sample of employees of the Faculty of History (University of Warsaw) and as such does not allow for concluding about the behavior of a bigger group. However, a comparison of these results with the studies conducted worldwide among the scholars of humanities suggests that the observed tendencies may aptly characterize Polish scholars. Research results indicate that the specificity of information behavior of the humanists has not changed over time as dramatically as it could have been expected considering the rapid development of digital technologies used in the research process. This can be viewed both from the perspective of scholars themselves, who still prefer the same methods of locating literature (browsing) and from the perspective of sources offered to them, that sadly, despite numerous research containing appropriate recommendations, are still largely inadequate for the needs of humanities scholars. 


\section{References}

Al-Shboul, M. K.; Abrizah, A. (2014). Information Needs: Developing Personas of Humanities Scholars. Journal of Academic Librarianship, 40(5), 500-509.

Bass, A.; Fairlee, J.; Fox, K.; Sullivan, J. (2005). The information behavior of scholars in the humanities and social sciences. Seattle: University of Washington.

Bates, M. J. (1996). The Getty end-user online searching project in the humanities: Report No 6: Overview and conclusions. College $\mathcal{E}$ Research Libraries, 57(6), 514-523.

Becker, G. S. (1964). Human Capital: A Theoretical and Empirical Analysis, with Special Reference to Education (Vol. 3d edition). Chicago: The University of Chicago Press.

Becker, G. S. (1990). Ekonomiczna teoria zachowań ludzkich. Warszawa: Wydaw. Naukowe PWN.

Blitzer, C. (1967). This wonderful machine: Some thoughts on computers and the humanities. In A. Bowles (Ed.), Computers in humanistic research. Englewood Cliffs, NJ.: Prentice-Hall.

Bouazza, A. (1989). Information user studies. In: Encyclopedia of Library and Information Science, 44, 144-164.

Brockman, W. S.; Neumann, L.; Palmer, C. L.; Tidline, T. J. (2001). Scholarly Work in the Humanities and the Evolving Information Environment. Washington DC: Digital Library Federation, Council on Library and Information Resources

Bronstein, J.;Baruchson-Arbib, S. (2008). The application of cost-benefit and least effort theories in studies of information seeking behavior of humanities scholars: The case of Jewish studies scholars in Israel. Journal of Information Science, 34(2), 131-144.

Buchanan, G.; Cunningham, S.; Blandford, A.; Rimmer, J.; Warwick, C. (2005). Information Seeking by Humanities Scholars. In: A. Rauber, S. Christodoulakis, A. Tjoa (Eds.), Research and Advanced Technology for Digital Libraries. Lecture Notes in Computer Science, Vol. 3652. Berlin: Springer, 218-229.

Dalton, M. S.; Charnigo, L. (2004). Historians and their information sources. College and Research Libraries, 65(8), 400-425.

Gould, C. C. (1988). Information needs in the humanities: An assessment. Stanford: The Group.

Graham, S. R. (2000). Historians and electronic resources: A citation analysis [online]. Journal of the Association for History and Computing, 3(3), [06.07.2015], http://quod.lib.umich.edu/j/ jahc/3310410.0003.308/--historians-and-electronic-resources-a-citation-analysis?rgn=main;vie$\mathrm{w}=$ fulltext

Jasińska-Kania, A. (2006). Teoria racjonalnego wyboru. In: A. Jasińska-Kania, L. Nijakowski, J. Szacki (Eds.), Wspótczesne teorie socjologiczne. Warszawa: Wydaw. Naukowe Scholar, 135-137.

Lissowski, G. (2002). Teoria racjonalnego wyboru. In: W. Kwaśniewicz (red.), Encyklopedia socjologii. Vol. 4. Warszawa: Oficyna Naukowa, 194-198.

Madden, R. (2014). Information behaviour of humanities PhDs on an information literacy course. Reference Services Review, 42(1), 90-107.

Mierzecka-Szczepańska, A. (2012). Ewaluacja efektywności systemów informacyjno-wyszukiwawczych - wybrane parametry ocen. In: B. Sosińska-Kalata, E. Chuchro (red.), Spoteczeństwo i sieć informacyjna. Problemy i technologie. Warszawa: : Wydaw. SBP, 111-124.

Mierzecka-Szczepańska, A. (2013). Badania zachowań informacyjnych. Warszawa: Wydaw. SBP.

Neumann, L. J. (2002). The Information Work of Interdisciplinary Humanities and Scholars: Exploration and Translation. Library Quarterly, 72(1), 85.

Palmer, C. L.; Neumann, L. J. (2002). The Information Work of Interdisciplinary Humanities and Scholars: Exploration and Translation. Library Quarterly, 72(1), 85.

Rimmer, J.; Warwick, C.; Blandford, A.; Gow, J.; Buchanan, G. (2006). Humanities scholars' information-seeking behaviour and use of digital resources - paper presented at workshop on digital libraries in the context of users' broader activities. The Joint Conference on Digital Libraries. 
Sosińska-Kalata, B. (2011). Nowe narzędzia organizacji wiedzy a jakość usług informacyjnych. In: D. Pietruch-Reizes, W. Babik (red.) Bezpieczna, innowacyjna i dostęna informacja - perspektywy dla sektora ustug informacyjnych w spoteczeństwie wiedzy. Katowice: PTIN, 95-109.

Stone, S. (1982). Humanities scholars. Information needs and uses. Journal of Documentation, 38(4), 292-313.

Tahir, M.; Mahmood, K.; Shafique, F. (2010). Use of electronic information resources and facilities by humanities scholars. The Electronic Library, 28(1), 122-136.

Talja, S.; Maula, H. (2003). Reasons for the use and non冈use of electronic journals and databases. Journal of Documentation, 59(6), 673-691.

Tibbo, H. R. (2003). Modeling the Information-Seeking Behavior of Social Scientists: Ellis's Study Revisited. Journal of the American Society for Information Science \& Technology, 54(6), 570.

Toms, E.; Flora, N. (2005). From physical to digital humanities library - designing the humanities scholar's workbench. In: R. Siemens, D. Moorman (Eds.) Mind Technologies: Humanities Computing and the Canadian Academic Community. Calgary: University of Calgary Press.

Toms, E.; O'Brien, H. L. (2008). Understanding the information and communication technology needs of the e-humanist. Journal of Documentation, 64(1), 102-130.

von Neumann, J.; Morgenstern, O. (1944). Theory of Game and Economic Behavior. New York: Wiley. Watson-Boone, R. (1994). The information needs and habits of humanities scholars. Reference Quarterly, 34, 203-216.

Whitmire, E. (2002). Disciplinary Difference and Undergraduates' Information-Seeking Behavior. Journal of the American Society for Information Science \& Technology, 53(8), 631-638.

Wiberley, S. E.; Jones, W. G. (2000). Time and Technology: A Decade-Long Look at Humanists' Use of Electronic Information Technology. College E Research Libraries, 61(5), 421-431.

\title{
Zachowania informacyjne w humanistyce: wyszukiwanie czy przeglądanie, kompletność czy dokładność? Badanie potrzeb informacyjnych naukowców: przypadek Wydziału Historycznego Uniwersytetu Warszawskiego
}

\begin{abstract}
Abstrakt
Cel/teza: Celem prowadzonych badań było poznanie charakterystyki zachowań informacyjnych naukowców, których specjalizacja mieści się w obrębie nauk humanistycznych. Uznając istotność uwarunkowań lokalnych i ich wpływ na zachowania informacyjne badaniem empirycznym objęto grupę naukowców polskich, pracowników naukowych Wydziału Historycznego Uniwersytetu Warszawskiego. Szczególny nacisk położono na ustalenie w jaki sposób naukowcy wyszukują potrzebną literaturę, jakie czynniki wpływają na satysfakcje z wyników kwerendy, jak ważny jest poziom relewancji wyników, czy istotniejsza w opinii naukowców będzie kompletność czy dokładność wyszukiwania. Koncepcja/metody badań: Badania empiryczne poprzedzono analizą literatury, która pozwoliła na ustalenie tendencji zachowań informacyjnych naukowców obserwowanych na świecie i postawienie tez badawczych w odniesieniu do środowiska naukowców polskich. Tezy były weryfikowane na podstawie 54 wywiadów pogłębionych przeprowadzonych z pracownikami Wydziału Historycznego Uniwersytetu Warszawskiego oraz zleconych przez nich kwerend literatury naukowej.

Wyniki i wnioski: Wyniki badania wykazały, że przedstawiciele nauk humanistycznych, jako metodę docierania do potrzebnej literatury preferują przeglądanie zbiorów dokumentów charakteryzujących
\end{abstract}


się wysokim poziomem kompletności. Ze względu na trudności z precyzyjnym formułowaniem instrukcji rzadziej wybieraną formą jest dążenie do wyszukania zbioru dokumentów o wysokim poziomie współczynnika dokładności. Konieczność przeglądania nierelewantnych pozycji nie ma istotnego wpływu na poziom satysfakcji użytkowników. Dodatkowo badania wykazały, że bazy piśmiennictwa naukowego nadal nie są dostosowane po potrzeb przedstawicieli nauk humanistycznych. Oryginalność/wartość poznawcza: Przeprowadzone badania pozwoliły na opisanie zachowań informacyjnych przedstawicieli nauk humanistycznych w kontekście wykorzystywania technologii cyfrowych w procesie badawczym, co do tej pory nie miało miejsca w odniesieniu do polskiego środowiska naukowego.

\section{Słowa kluczowe}

Dokładność informacji. Humaniści. Kompletność informacji. Potrzeby informacyjne. Przeglądanie informacji. Relewancja przedmiotowa. Satysfakcja użytkowników informacji. Wyszukiwanie informacji. Zachowania informacyjne.

Dr ANNA MIERZECKA is an Assistant Professor at the Institute of Information and Book Studies of the University of Warsaw. She specializes in the research on users' information behavior, with a particular emphasis on academic communication and the issues of e-participation. She is the author of the book "Badania zachowan informacyjnych" [Study of Information Behavior] (2013), awarded the 2013 Eysakowski prize for academic merit and the 2014 Clio prize, as well as several papers on the use of information resources.

Contact to the author:

anna.mierzecka@uw.edu.pl

Institute of Information Science and Book Studies

University of Warsaw

Krakowskie Przedmieście 26/28

00-927 Warsaw 